\title{
Testing Capital Structure Theories Using Error Correction Models: EVIDENCE FROM THE UK, FRANCE AND GERMANY
}

\begin{abstract}
We employ an error correction model of leverage to test the trade-off and pecking order theories of capital structure for firms in the UK, France and Germany. The error correction framework extends the partial adjustment model by explicitly modelling changes in target leverage and past deviations from such target as determinants of firms' dynamic leverage adjustment process. We also augment our empirical models to test the pecking order theory. Using appropriate and advanced dynamic panel data methods, we find that UK, French and German firms adjust towards target leverage quickly in both the partial adjustment and error correction models, which is consistent with the trade-off theory. We further show that the trade-off theory explains these firms' capital structure decisions better than the pecking order theory in the models nesting the two theories.
\end{abstract}

JEL Classification: G32.

Keywords: Capital structure, Trade-off theory, Pecking order theory, Partial adjustment, Error correction model. 


\section{Introduction}

Since Modigliani and Miller's (1958) (hereafter MM) irrelevance theorem, the major body of capital structure research has attempted to examine whether firms' financing decisions matter by relaxing MM's restrictive assumptions and considering market frictions and imperfections such as financial distress, taxes, agency problems and asymmetric information (see Harris and Raviv, 1991; Myers, 2001; Frank and Goyal, 2007 for reviews). In particular, this research agenda has advanced two dominant theories of capital structure, namely the trade-off and pecking order theories. ${ }^{1}$ In this paper, we provide new international evidence on these two theories using novel empirical models.

The trade-off theory considers the benefits and costs of debt financing in the presence of taxes, costly bankruptcy (e.g., Kraus and Litzenberger, 1973; Bradley et al., 1984) as well as incentive problems (Jensen and Meckling, 1976). Debt is financially beneficial because it has a tax advantage treatment (i.e., debt tax shields) that allows firms to reduce their expected tax bill and increase their after-tax cash flows (Modigliani and Miller, 1963). Another potential benefit of debt is its disciplining role to help mitigate agency costs associated with the risk-shifting problem, the asset substitution effect (Jensen and Meckling, 1976) as well as the free cash flow problem (Jensen, 1986). The disadvantages of debt are due to costly financial distress and bankruptcy as well as agency problems such as overinvestment (Jensen and Meckling, 1976) or underinvestment incentives (Myers, 1977). Overall, the trade-off theory predicts that firms should balance the benefits against the costs of debt and, thus, should have optimal capital structure.

Empirical studies testing the trade-off theory focus on its key prediction that firms have an optimal debt ratio (i.e., target leverage) but due to transaction costs, may temporarily deviate from such target and seek to adjust towards it. To examine this dynamic adjustment behaviour, most studies have employed a partial adjustment model of leverage that captures the actual leverage change as a fraction of the desired change towards target leverage. Early studies using this model provide mixed evidence for active dynamic adjustment of leverage. While Ozkan (2001) shows that UK firms have a relatively fast speed of adjustment (above 50\%), Fama and French (2002) find that US firms adjust towards their target leverage at a very slow speed ranging from $7 \%$ to $18 \%$. However, recent empirical studies using advanced

\footnotetext{
${ }^{1}$ Recent research has also developed two alternative hypotheses, namely the market-timing hypothesis (Baker and Wurgler, 2002) and managerial inertia hypothesis (Welch, 2004), in which capital market conditions are of first-order importance to firms' external financing decisions (see Frank and Goyal, 2007 for a review). Nevertheless, these two hypotheses are not the focus of this paper.
} 
econometric techniques for dynamic panel data models provide stronger support for the tradeoff theory. Flannery and Rangan (2006) find that US firms adjust towards target leverage quite actively at an annual adjustment speed of over 30\%. ${ }^{2}$ Antoniou et al. (2008) show that firms in France, the US, the UK and Germany all undertake partial adjustment towards their target leverage at relatively quick speeds.

The pecking order theory considers the problem of information asymmetries in which the shareholders/managers of a firm know more about the value of its assets in place and future growth prospects than do the outside investors (Myers, 1984; Myers and Majluf, 1984). Under this framework, it is difficult for investors to distinguish between securities of high-quality and those of low-quality firms. Therefore, high-quality firms have little incentive to issue new securities that are susceptible to under-pricing, leading to an adverse selection problem and partial market failure in the capital market. ${ }^{3}$ To mitigate this problem, firms prefer to rely on the source of financing that is less risky and sensitive to valuation errors. This behaviour consequently leads to a pecking order of financing choice in which internal funds are preferred to external finance and debt is preferred to equity. In contrast with the trade-off theory, the pecking order theory does not predict that firms have well-defined target leverage.

The existing empirical evidence for the pecking order theory is far from conclusive. Shyam-Sunder and Myers (1999) were the first to propose a direct test for the second rung of the pecking order of financing in which debt is a preferred source of external finance to equity. Specifically, they examined the relation between firms' net debt issues and financing deficit (or surplus) and found that firms mainly used debt policies to offset their financing deficit (or surplus), which was consistent with their interpretation of the pecking order theory. Frank and Goyal (2003) examine a broader sample of US firms over a longer period and document inconclusive evidence for Shyam-Sunder and Myers' (1999) model. Seifert and Gonenc (2008) estimate a series of similar models for a sample of firms in the UK, the US and Germany and find little support for the pecking order theory. Most recently, however,

\footnotetext{
${ }^{2}$ Recent US evidence documents a slower speed of adjustment, in the range between $17 \%$ and $25 \%$ (see, for example, Lemmon et al., 2008; Huang and Ritter, 2009). Hence, the question of whether US firms do undertake active and fast adjustment towards target leverage is not yet settled.

${ }^{3}$ Note, however, that high-quality firms may signal their type to the market through capital structure decisions. See a series of signalling models by Ross (1977), Leland and Pyle (1977) and Heinkel (1982).
} 
Lemmon and Zender (2010) provide some empirical support for a "modified" version of the pecking order theory that incorporates the concept of debt capacity. ${ }^{4}$

The above review suggests that past empirical studies tend to test the trade-off or pecking order theories in isolation. However, a recent trend of research has attempted to examine both theories simultaneously. Shyam-Sunder and Myers (1999), for example, augment their pecking order model to nest the trade-off theory in a single specification; they subsequently find that the pecking order theory outperforms the trade-off theory in this nested model. However, recent studies have provided mixed evidence for the pecking order and the trade-off theories. Leary and Roberts (2005) show that US firms dynamically rebalance their capital structure, which is more consistent with the trade-off theory. Flannery and Rangan (2006) find that US firms' financing behaviours follow the trade-off framework more closely than alternative views of capital structure, including the pecking order theory. Dang (2010) further shows that the trade-off theory explains UK firms' capital structure decisions much better than the pecking order theory. Most recently, however, de Jong et al. (2011) find that the trade-off and pecking order theories are respectively relevant to firms' decisions to repurchase and issue new securities. Overall, the question of whether the trade-off and pecking order theories can better explain firms' actual financing decisions remains an interesting and relevant one that deserves further research.

In this paper, we contribute to the empirical capital structure literature in the following ways. First, we employ an empirical model that better captures the trade-off theory's prediction about firms' dynamic adjustment towards target leverage than existing models. Specifically, we extend the widely-used partial adjustment model of leverage into a more general specification, namely an error correction model. The latter framework explicitly models target leverage change and past deviations from target leverage over time as the driving forces underlying firms' dynamic adjustment behaviour. In testing the trade-off theory, it is important to control for changes in target leverage for the following reasons. Theoretically, target leverage must balance the benefits (e.g., debt tax shields) and costs (e.g., financial distress and/or agency problems) of debt, both of which depend on the time-varying firm characteristics. ${ }^{5}$ In addition, in most empirical studies, target leverage is proxied by the fitted values from a regression of leverage on a set of firm characteristics. Thus, any changes

\footnotetext{
${ }^{4}$ See also Fama and French (2005), who reveal some patterns of corporate equity issues that are in stark contrast with the pecking order theory.

${ }^{5}$ For example, a firm's probability of financial distress and the associated costs are determined by its size, profitability, earnings' volatility and credit ratings etc, which do not remain constant overtime.
} 
in the latter factors will also lead to changes in target leverage. As another contribution in terms of modelling, we further augment the partial adjustment and error correction models of leverage to nest the pecking order theory in unifying specifications that allow us to examine the trade-off and pecking order theories jointly.

Second, we employ appropriate and advanced dynamic panel data estimators to estimate the speed of leverage adjustment in the partial adjustment and error correction models. Existing research studies employing a two-stage procedure to estimate the partial adjustment model of leverage use traditional methods such as the Fama-MacBeth (1973), pooled OLS and/or fixed effects estimators (e.g., Shyam-Sunder and Myers; 1999; Fama and French, 2002; Frank and Goyal, 2003; Byoun, 2008). ${ }^{6}$ However, it is well-established in the econometrics literature that these methods provide biased estimates in dynamic panel data models, especially in the likely presence of individual firm fixed-effects and short panel lengths (see Baltagi, 2008). Simply put, they may produce estimated speeds of adjustment that are unreliable, thus potentially leading to misleading evidence for the trade-off theory. In this paper, we adopt Anderson and Hsiao's (1982) instrumental variable estimator (hereafter AHIV), Arellano and Bond's (1991) and Blundell and Bond's (1998) generalised methods of moments estimators (hereafter GMM and SYSGMM, respectively) to improve the consistency and efficiency of our estimates of the speed of leverage adjustment.

Finally, our proposed empirical framework will be tested against a comprehensive sample of firms in the UK, Germany and France between 1980 and 2007. While recent empirical studies have started to examine capital structure decisions using international data (see, among others, Rajan and Zingales, 1995; Wald, 1999; de Jong et al., 2008; Antoniou et al., 2008), very few of them have tested both the trade-off and pecking order theories jointly using non-US data. ${ }^{7,8}$ This is a significant omission because it is of interest to examine dominant capital structure theories in other macroeconomic environments. We focus on firms in the UK, Germany and France for two main reasons. First, these countries represent the

\footnotetext{
${ }^{6}$ The two-stage procedure involves estimating target leverage before estimating the partial adjustment and error correction models. It is different from the one-stage approach where target leverage is not estimated but is substituted into the latter models to be estimated in one step. We discuss this procedure in detail in Section 2.1.

${ }^{7}$ There is a growing literature examining UK firms. See, for example, Bennett and Donnelly (1993), Ozkan (2001), Bevan and Danbolt (2002, 2004), Watson and Wilson (2002). However, these studies have only examined the determinants of capital structure, or either the trade-off theory or the pecking order theory.

${ }^{8}$ An exception is Dang (2010), who also develops an error correction model of leverage to investigate the tradeoff and pecking order theories jointly. However, his sample is limited to a small sample of UK firms over a short period between 1996 and 2003 while, methodologically, his two-stage model is estimated using the OLS or the fixed-effects estimators as in prior research, which are most likely to produce biased estimates.
} 
most developed economies outside the US and, thus, are the most natural testing ground for modern capital structure theories. Second, these countries also represent two distinct economic systems with the UK being another market-based economy with similar macroeconomic characteristics to the US and Germany and France being typical bank-based economies with different financial and institutional differences to those of the US and UK (Antoniou et al., 2008). Hence, our results are expected to provide new and important evidence on capital structure theories in different markets and macroeconomic systems.

As a preview of our results, we first find that target leverage and firm characteristics (e.g., collateral value of assets, growth opportunities and firm size) have significant relations as predicted by the trade-off theory. Second, we show that UK, German and French firms adjust relatively quickly towards their target leverage in both the partial adjustment and error correction models. Third, we show that the error correction model is a better specification to test firms' dynamic adjustment towards target leverage. In particular, the results reveal that firms adjust towards target leverage the most quickly in response to target leverage change, at a speed of adjustment ranging between 0.776 and 0.933 . The speed of adjustment in response to past deviations from target leverage is significantly slower, ranging from 0.390 to 0.454 . Taken together, these findings are strongly in line with the trade-off theory. Finally, we show that pecking order considerations are of minor importance to UK, German and French firms. Our results suggest that the trade-off theory consistently outperforms the pecking order theory in nested models that capture the predictions of the two theories.

The remainder of the paper is organised as follows. Section 2 develops the empirical models and discusses the econometric methods used. Section 3 describes the data and provides the summary statistics. Section 4 reports and interprets the empirical results. Section 6 concludes the paper.

\section{Empirical Models and Methods}

\subsection{Partial Adjustment Model}

We first follow the convention of previous research (e.g., Ozkan, 2001; Fama and French, 2002; Flannery and Rangan, 2006) and adopt a dynamic, partial adjustment model of leverage to test the prediction of the trade-off theory that firms move partially towards their target leverage. Formally, this partial adjustment model is specified as follows:

$$
\Delta D_{i t}=\alpha+\lambda\left(D_{i t}^{*}-D_{i t-1}\right)+u_{i t},
$$

or 


$$
\Delta D_{i t}=\alpha+\lambda T L D_{i t}+u_{i t}
$$

where $D_{i t}$ and $D_{i t}{ }^{*}$ represent the actual and target leverage for firm $i$ at time $t$, respectively. $T L D_{i t}$ is the deviation from target leverage such that $T L D_{i t}=D_{i t}{ }^{*}-D_{i t-1} \cdot u_{i t}$ is the wellbehaved error term. $\lambda$ is the speed of adjustment, which measures the proportion of the actual leverage change, $\Delta D_{i t}$, to the desired leverage change, $T L D_{i t}$. The speed of adjustment would be equal to unity if firms could adjust to their target leverage instantaneously. In the presence of leverage adjustment costs, however, it is expected to be between 0 and $1 .{ }^{9}$ Empirically, a coefficient estimate in the range of 0.30 and above is interpreted as a relatively quick speed of adjustment and one that is consistent with the trade-off theory (see, for example, Flannery and Rangan, 2006). Firms in bank-based economies such as Germany and France may face lower adjustment costs thanks to close business relationships with their banks, suggesting the adjustment speed for these firms may be faster than that for firms in a market-based economy such as the UK.

In order to estimate Equation (2), we need to find a proxy for target leverage, $D_{i t}{ }^{*}$. Following the conventional approach adopted in literature (e.g., Byoun, 2008), we model target leverage as a function of firm characteristics, as follows:

$$
D_{i t}^{*}=\boldsymbol{\beta}^{\prime} \mathbf{x}+w_{i t},
$$

where $\mathbf{x}$ is a vector of firm characteristics and $\boldsymbol{\beta}$ is the associated vector of the parameters. $w_{i t}$ is an error component that includes firm and/or industry fixed-effects, $\mu_{t}$, such that $w_{i t}=\mu_{t}+u_{i t}$, where $u_{i t}$ is the i.i.d error term. The firm and or industry fixed-effects control for time-invariant unobservable, unique firm and/or industry characteristics, such as managerial skills, the life cycle of products and firm competitiveness etc, which cannot be captured by $\mathbf{x}$ (Ozkan, 2001; Dang, 2011). We will discuss the firm characteristics included in $\mathbf{x}$ in detail in Section 2.3.

Our estimation strategies can be described as follows. We adopt a two-stage estimation procedure (Shyam-Sunder and Myers, 1999; Fama and French, 2002; Byoun, 2008), in which we first estimate Equation (3) and obtain the fitted values, $\hat{D}_{i t}=\hat{\boldsymbol{\beta}}^{\prime} \mathbf{x}$ (where

\footnotetext{
${ }^{9}$ See also Fischer et al. (1989) and Leary and Roberts (2005) for models with costly adjustment.
} 
$\hat{\boldsymbol{\beta}}$ is a consistent estimate of $\boldsymbol{\beta})$, as a proxy for target leverage $\left(D_{i t}^{*}\right)$ before estimating Equation (2). ${ }^{10}$

In terms of econometric techniques, we only consider recently developed estimators for dynamic panel data models when estimating Equation (2). It is well-established in the literature that applying traditional methods such as the pooled $O L S$ and fixed-effects estimators to a dynamic panel data model such as (2) will produce biased estimates due to the correlation between $T L D_{i t}$ (via $D_{i t-1}$ ) and $u_{i t}$, especially in short panels with unobserved individual firm fixed-effects (e.g., Nickell, 1981; Baltagi, 2008). Importantly, such biases may lead to inaccurate and unreliable estimates of the speed of adjustment, hence invalidating tests of the trade-off theory.

To overcome the drawback of the pooled $O L S$ and fixed-effects estimators, we employ the following methods: Anderson and Hsiao's (1982) instrumental variable estimator (AHIV), Arellano and Bond's (1991) GMM (GMM) and Blundell and Bond's (1998) system GMM (SYSGMM). These estimators apply the first-differencing transformation to Equation (2) to yield:

$$
\Delta^{2} D_{i t}=\lambda \Delta T L D_{i t}+\Delta u_{i t} .
$$

Next, to adopt the AHIV estimator, we use the (first) lagged value, $T L D_{i t-1}$ as an instrument for $\triangle T L D_{i t}$. Although the AHIV approach provides consistent estimates of the adjustment speed, it is potentially inefficient for not taking into account all the moment conditions available in (2). Hence, we also adopt the more efficient GMM estimator that exploits all the linear restrictions in (2) under the assumption of no serial correlation. ${ }^{11}$ Specifically, based on the orthogonality conditions between the lagged values of $T L D_{i t}$ and the error term, $\Delta u_{i t}$, we follow Arellano and Bond (1991) and use all these lagged values, i.e., $\left(T L D_{i t-1}, T L D_{i t-2}, ., T L D_{i 1}\right)$ as instruments for $\triangle T L D_{i t}$. Finally, we also employ the SYSGMM estimator that considers additional moment conditions in the level equation (2) where it adopts $\left(\triangle T L D_{i t-1}, \Delta T L D_{i t-2}, . ., \Delta T L D_{i 1}\right)$ as instruments for $T L D_{i t}$ under the orthogonality conditions between these instruments and $u_{i t}$ (Blundell and Bond, 1998). This SYSGMM

\footnotetext{
${ }^{10}$ While this procedure is intuitive and easy to implement, it has a potential limitation in that any estimation errors in the first stage will be carried into the second stage when Equation (2) is estimated. An alternative procedure involves substituting (3) directly into (2), yielding a dynamic panel data model that can be estimated in one-stage (see, among others, Ozkan, 2001; Flannery and Rangan, 2006).

${ }^{11}$ This is equivalent to having no second-order correlation in the first-differenced equation (4). Hence, the consistency of the GMM depends on the absence of second-order correlation.
} 
estimator is supposed to improve the consistency and efficiency of Arellano and Bond's GMM estimator, especially in short panels when the data are highly persistent (Blundell and Bond, 1998). Finally, we follow Arellano and Bond (1991) and employ (1) the AR2 test to check the important condition of no second-order correlation in the (differenced) error term and (2) the Sargan test to check the validity of the instruments used.

\subsection{Error Correction Model}

While the partial adjustment model of leverage specified by Equation (2) has been used widely in the corporate finance literature to investigate firms' dynamic adjustment towards target leverage (e.g., Ozkan, 2001; Flannery and Rangan, 2006; Byoun, 2008), it is based on the assumption that the costs of adjusting leverage is independent of target leverage change. An alternative and more reasonable assumption is, however, that the adjustment costs can also be partially reduced when there is movement towards target leverage (Maddala, 2001). A natural extension of the partial adjustment model, therefore, involves explicitly modelling target leverage changes as well as their effect on the dynamic leverage adjustment process through a more general specification, namely an error correction model (see also Dang, 2010). ${ }^{12}$

Formally, the error correction model of leverage can be specified as follows:

$$
\Delta D_{i t}=\alpha+\lambda\left(D_{i t}^{*}-D^{*}{ }_{i t-1}\right)+\gamma\left(D^{*}{ }_{i t-1}-D_{i t-1}\right)+u_{i t},
$$

or

$$
\Delta D_{i t}=\alpha+\lambda T L C_{i t}+\gamma L E C M_{i t}+u_{i t},
$$

where $\lambda$ and $\gamma$ are the speeds of leverage adjustment towards the target. The first term on the right hand side of (6), $T L C_{i t}$, represents the change in target leverage over time and the second term, $L E C M_{i t}$, is the deviation of actual leverage from target leverage in the last accounting period. Unlike the partial adjustment model (2), the error correction model (6) explicitly controls for the change in target leverage caused by shocks to its determining factors (i.e., firm characteristics) and its effects on leverage adjustment costs and adjustment process. Note that the error correction model is a generalised version of the partial adjustment model; the former model effectively becomes the latter when the two speeds of adjustment are equal, i.e., $\lambda=\gamma$.

In estimating the error correction model (6), we adopt the same two-stage procedure proposed for estimating the partial adjustment model (2). Specifically, we proxy for target

\footnotetext{
12 Another potential extension is to allow for firms' asymmetric adjustment conditional on their deviations from target leverage, financing gaps and other firm-specific characteristics (see Byoun, 2008; Dang et al., 2009).
} 
leverage in (6) by using the fitted values from the first-stage estimation of Equation (3). In terms of the econometric methods, we only use the AHIV, GMM and SYSGMM estimators to obtain consistent and efficient estimates of the adjustment speeds. These methods first involve first-differencing Equation (6), as follows:

$$
\Delta^{2} D_{i t}=\lambda \Delta T L C_{i t}+\gamma \Delta L E C M_{i t}+\Delta u_{i t} .
$$

Next, we employ the AHIV estimator by using $T L C_{i t-1}$ and $L E C M_{i t-1}$ as instruments for $\triangle T L C_{i t}$ and $\triangle L E C M_{i t}$ in (7), respectively. Regarding the GMM estimator, we use the vectors $\left(T L C_{i t-1}, T L C_{i t-2}, . ., T L C_{i 1}\right)$ and $\left(L E C M_{i t-1}, L E C M_{i t-2}, . ., L E C M_{i 1}\right)$ as instruments for $\Delta T L C_{i t}$ and $\triangle L E C M_{i t}$, respectively. Finally, we apply the SYSGMM estimator by employing the same instruments as the GMM estimator as well as two additional sets of instruments $\left(\Delta T L C_{i t-1}, \Delta T L C_{i t-2}, . ., \Delta T L C_{i 1}\right)$ and $\left(\Delta L E C M_{i t-1}, \Delta L E C M_{i t-2}, . ., \Delta L E C M_{i 1}\right)$ for $T L C_{i t}$ and $L E C M_{i t}$ in the level equation (6), respectively.

\section{3. $\quad$ Target Leverage and its Determinants}

To specify $\mathbf{x}$ in the estimation of target leverage in (3), we follow the literature (Titman and Wessels, 1988; Rajan and Zingales, 1995; Frank and Goyal, 2009) and consider the five most commonly-used determinants of leverage, namely, (1) the collateral value of assets, (2) non-debt tax shields, (3) profitability, (4) growth opportunities and (5) firm size. The following subsection discusses these factors and the expected relations between them and target leverage.

Collateral value of assets. The trade-off view suggests that firms with more collateral can borrow more debt as they face lower financial distress/bankruptcy costs. In addition, collateral can be used as a security to mitigate the risk-shifting and asset substitution problem (Jensen and Meckling, 1976), thus reducing the agency costs of debt. In short, under the trade-off framework, the collateral value of assets and target leverage should have a positive relation. However, the pecking order theory predicts that firms with less collateral face higher information costs and, thus, prefer debt to equity (see Harris and Raviv, 1991). In other words, collateral and target leverage are negatively related. We measure the collateral value of assets by the ratio of fixed assets to total assets.

Non-debt tax shields. Firms that can benefit from non-debt tax shields have less incentive to exploit the tax advantage of debt financing (DeAngelo and Masulis, 1980). Since non-debt tax shields may substitute for debt tax shields, the trade-off theory predicts that nondebt tax shields and target leverage have a negative relation. In the empirical analysis, we use the ratio of depreciation to total assets as a proxy for non-debt tax shields. 
Profitability. The trade-off theory predicts a positive relation between profitability and leverage as profitable firms have strong incentive to raise debt capital to exploit the tax advantage of debt, i.e., debt tax shields (Modigliani and Miller, 1963). In addition, under the agency framework, profitable firms may experience the free cash flow problem, which they can mitigate by using debt as a discipline device (Jensen, 1986). In contrast, the pecking order theory has a conflicting prediction: profitability and leverage should be negatively associated (Myers and Majluf, 1984). Profitable firms are likely to have sufficient retained earnings to fund future investment opportunities so they can rely less on external financing sources, including debt. In this paper, profitability is measured by the ratio of EBITDA to total assets.

Growth opportunities. Firms with high growth opportunities are likely to suffer from financial distress and the debt overhang problem (Myers, 1977). As a result, these firms have strong incentive to rely more on equity than on debt finance. On the other hand, low-growth firms operating in mature industries may use debt as a discipline device to alleviate the free cash flow problem (Jensen, 1986). Thus, under the trade-off framework, growth opportunities and leverage should have a negative relation. We use the market-to-book ratio as a proxy for growth opportunities.

Firm size. The trade-off theory suggests that large firms face lower financial distress and agency costs and, thus, are able to borrow more than small firms. The implication follows that firm size has a positive effect on target leverage. However, the former firms face lower information costs and can raise equity capital more easily than the latter firms (see Frank and Goyal, 2009). Thus, in the presence of asymmetric information, firm size and target leverage may have a negative relation. We measure firm size by the natural logarithm of total assets, adjusted for inflation.

\subsection{Pecking Order Model}

In one of the first direct tests of the pecking order theory, Shyam-Sunder and Myers (1999) develop a simple empirical framework that captures the second rung of the pecking order of firms' financing choice. Their model tests the prediction that when a firm raises external finance, it will mainly use debt but not equity. After having an initial public offering (IPO), the firm rarely issues additional equity unless it has used up its debt capacity or faces extremely high bankruptcy costs that make borrowing impossible. Formally, Shyam-Sunder and Myers' (1999) empirical model takes the following form:

$$
\Delta D_{i t}=\alpha+\beta D E F_{i t}+\varepsilon_{i t},
$$


where $\Delta D_{i t}$ is the change in market leverage, ${ }^{13} \varepsilon_{i t}$ is the i.i.d error term. $D E F_{i t}$ represents the financing deficit or surplus for firm $i$ in year $t$. We follow Shyam-Sunder and Myers (1999) and Frank and Goyal (2003) and define this variable as follows:

$$
D E F=-C F+I+D I V+\Delta C,
$$

where $C F$ is cash flow from operating activities less investment return and servicing of finance as well as taxation, $I$ is net investment, $D I V$ is dividends paid, and $\Delta C$ is the net change in cash. Finally, since Equation (8) is a static model, it will be estimated using the fixed-effects estimator, rather than dynamic panel data methods outlined in previous sections.

Shyam-Sunder and Myers (1999) argue that the pecking order theory holds if and only if $\alpha=0$ and $\beta=1$, i.e., when firms only raise (retire) debt to offset by their financing deficit (surplus). ${ }^{14,15}$ According to Seifert and Gonenc (2008), firms in Germany and France (bank-based economies) may face a more severe asymmetric information problem than firms in the UK (market-based economy) so we expect the pecking order theory to hold better for firms in the former countries than for those in the latter country.

\subsection{Augmented Partial Adjustment and Error Correction Models}

The empirical models developed in the previous sections can only be used to test the trade-off and pecking order theories separately. In this section, we consider a nested model that embeds both theories and allows us to test them jointly. We follow the spirit of ShyamSunder and Myers (1999) and Frank and Goyal (2003) and augment the partial adjustment model (2) by adding the financing deficit/surplus variable, $D E F_{i t}$, defined in (9), to derive the following nested model:

$$
\Delta D_{i t}=\alpha+\delta T L D+\beta D E F_{i t}+u_{i t} .
$$

In this model, the pecking order theory holds and explains firms' capital structure better than the trade-off theory if firms offset their financing deficit or surplus mainly by debt policies, i.e., $\alpha=0$ and $\beta=1$, and that they do not make active leverage adjustment towards the target, i.e., $\delta=0$. In contrast, if the adjustment speed is relatively fast (e.g., $\delta \geq 0.3$ ) and that

\footnotetext{
${ }^{13}$ Shyam-Sunders and Myers (1999) and Frank and Goyal (2003) consider three main proxies for the dependent variable in Equation (8), including total leverage change, net debt issued and gross debt issued, all scaled by the firm value. We focus on the first proxy in our empirical analysis because it allows us to develop the augmented partial adjustment and error correction models that nest both the trade-off and pecking order theories. However, the (unreported) results for the pecking order theory are qualitatively similar when we use the other two proxies.

${ }^{14}$ Recent research shows that the coefficient on $D E F, \beta$, may be asymmetric, depending on whether there is a financing deficit $(D E F>0)$ or surplus $(D E F<0)$. See, for example, de Jong et al. (2010).

${ }^{15}$ Shyam-Sunder and Myers' (1999) pecking order model has been criticised for having a low power in rejecting alternative theories. See Chirinko and Singha (2000).
} 
the financing deficit coefficient is significantly less than $1, \beta<1$, then the trade-off theory can be said to outperform the pecking order theory. Note that in estimating (10), we follow the same two-stage procedure and use the AHIV, GMM and SYSGMM estimators detailed above.

Finally, we augment the error correction model (6) by incorporating the financing deficit/surplus variable as follows:

$$
\Delta D_{i t}=\alpha+\lambda T L C+\gamma L E C M+\beta D E F_{i t}+u_{i t} .
$$

The pecking order theory holds that $\alpha=0, \beta=1$ and $\lambda=\gamma=0$ while the trade-off theory predicts the opposite. Finally, Equation (11) will be estimated using the same two-stage procedure mentioned above.

\section{Data, Sample Selection and Descriptive Statistics}

We investigate a large panel of firms in the most advanced economies in Europe, namely the UK, France and Germany. These three countries also represent two main types of economic systems, namely market-based (the UK) and bank-based economies (France and Germany). We collected our data from the Worldscope database over the period 1980-2007. We follow the standard practice in the literature (e.g., Ozkan, 2001) and apply a number of data restrictions. First, we remove financial and utility firms because they are subject to different regulatory accounting considerations. Second, we only retain firms that have fiveyears or more of observations in order to use the AHIV, GMM and SYSGMM estimators that require the use of lagged variables as instruments. Third, we remove firm-year observations that have missing data for the variables of interest. Fourth, we winsorise all the variables at the $1 \%$ and $99 \%$ to mitigate the impact of outliers in our empirical analysis. Our final sample comprises 2,102 firms with 17,778 firm-year observations. Specifically, it consists of 1,340 firms in the UK (with 11,635 observations), 446 firms in Germany (with 3,640 observations) and 316 firms in France (with 2,503 observations).

[Insert Table 1 about here]

Panels A, B and C of Table 1 report the descriptive statistics for UK, German and French firms, respectively. A general examination of these statistics reveals several interesting empirical facts. First, firms in the UK have substantially lower (market) leverage ratio (0.191) than firms in Germany (0.278) and France (0.294). This finding is consistent with previous international evidence (Rajan and Zingales, 1995; Antoniou et al., 2008) that firms in market-based economies (e.g., the UK) use debt more conservatively than firms in bank-oriented economies (e.g., Germany and France). Firms in market-based economies have 
dispersed share ownership and hence a preference for equity capital. On the contrary, firms in bank-based economies have strong incentive to use debt finance because, thanks to their close banking relationships, they are able to borrow at low costs.

The mean collateral value of assets (i.e., tangibility) is higher for UK firms (0.296) than for German firms (0.249) and French firms (0.194). This finding is plausible because UK firms have looser ties with their banks and so they have to satisfy stricter collateral requirements than those in bank-oriented economies.

UK firms have substantially more growth opportunities than German and French firms. High-growth firms face potentially high costs of financial distress and underinvestment incentives so they may prefer equity to debt finance, which is consistent with the above finding that UK firms have lower leverage ratios than other firms in the sample. In addition, since growth opportunities are measured by the market-to-book ratio, high-growth firms may be overvalued and, thus, have incentives to take advantage of this misvaluation by tapping in cheaper equity (i.e., market timing).

Finally, the descriptive statistics for firm size reveal that German and French firms have a tendency to remain private until they are sufficiently large and need to access additional sources of capital. In contrast, in market-based economies with favourable capital market conditions (e.g., the UK), firms with smaller size are able to access the equity market and source capital more easily.

\section{Empirical Results}

\subsection{Target Leverage Estimations}

Table 2 reports the empirical results from our estimations of target leverage, modelled by Equation (3). An overall assessment suggests that the results are comparable for UK, German and French firms. Moreover, they are statistically significant and most consistent with the predictions of the trade-off theory.

[Insert Table 2 about here]

The results show that the collateral value of assets has a positive effect on leverage. This finding is consistent with the trade-off view that firms with more collateralised assets face lower bankruptcy costs and, thus, are able to borrow more. It is also in line with the agency framework that predicts firms use their collateral to mitigate the asset substitution effect and the agency costs of debt. Empirically, our finding is consistent with previous empirical evidence (e.g., Rajan and Zingales, 1995; Antoniou et al., 2008; de Jong et al., 2008). 
The results regarding non-debt tax shields are mixed and inconsistent with the tradeoff theory. Specifically, this variable is significantly positive for UK and French firms but is insignificant for German firms. Unlike the existing evidence in the literature (e.g., Antoniou et al., 2008), these findings suggest that firms our the sample countries do not use non-debt tax shields as a substitute for debt tax shields as predicted by the trade-off framework (DeAngelo and Masulis, 1980).

The results show that profitable firms in the UK, Germany and France have lower leverage than less profitable firms. This finding appears to be most consistent with the pecking order theory's prediction that firms with large profits and sufficient retained earnings are less likely to rely on debt financing. It is often interpreted to be inconsistent with the static trade-off theory that predicts profitable firms should use more debt to shelter from corporate taxes. However, profitability may also proxy for growth opportunities such that a negative relation between profitability and leverage is also in line with the trade-off view (Frank and Goyal, 2007). Further, in dynamic trade-off settings, profitable firms may choose to hold on to their retained earnings to take advantage of future investment opportunities, thus resulting in lower leverage (e.g., Hennessy and Whited, 2006; Strebulaev, 2007). Empirically, our results are consistent with the well-documented international evidence on the relation between leverage and profitability (e.g., Rajan and Zingales, 1995; Antoniou et al., 2008).

Growth opportunities have a negative and significant effect on leverage across firms in our sample countries, which is consistent with the trade-off view. Specifically, under the agency framework, firms with high (low) growth options are more likely to use less (more) debt to mitigate the underinvestment (overinvestment) problem. This finding is strongly in line with previous empirical evidence (e.g., Rajan and Zingales, 1995; de Jong et al., 2008; Antoniou et al., 2008).

The results for UK, German and France firms show that target leverage is significantly and positively associated with firm size. This finding is consistent with the trade-off argument that large firms face lower financial distress and bankruptcy costs as well as agency and transaction costs, hence having stronger incentives to lever up to exploit debt tax shields. Empirically, our results are broadly in line with the previous empirical evidence (e.g., Antoniou et al., 2008).

In sum, the regression results for target leverage are both theoretically and empirically plausible for firms in the sample countries. Moreover, they are consistent with the predictions of the trade-off theory about the relations between target leverage and its determinants. The 
latter finding is important because it suggests target leverage is well-defined such that it is appropriate to test how firms adjust towards such target. ${ }^{16}$

\subsection{Results for the Partial Adjustment Model}

Table 3 contains the results for the trade-off theory, modelled by the partial adjustment model (2). Columns (1)-(3), (4)-(6) and (7)-(9) report the results for UK, German, and French firms, respectively. Columns (1), (4) and (7) use the AHIV estimator. Columns (2), (5) and (8) adopt the GMM estimator and columns (3), (6) and (9) adopt the SYSGMM estimator. We further report the AR2 and Sargan test statistics to evaluate the validity of the dynamic panel data methods used.

[Insert Table 3 about here]

Overall, all the estimation results are satisfactory. The AR2 test results show no evidence of second autocorrelation, suggesting the instruments used in estimating the panel dynamic data model (2) are appropriate. However, the Sargan test is rejected at the $1 \%$ significance level in the GMM and SYSGMM models for UK firms; it is also rejected in the SYSGMM model for German firms. This suggests that these specific GMM and SYSGMM results may suffer from the over-identification problem and, therefore, should be treated with caution.

The coefficient on $T L D_{i t}$, which represents the speed of adjustment, is statistically and economically significant in all models. A general observation of the results shows that the AHIV estimates of the adjustment speed are the smallest, followed by the GMM and SYSGMM estimates, both of which are nevertheless fairly similar in magnitude (except for German firms). This finding suggests that using GMM and SYSGMM can potentially overcome the (downward) bias of the AHIV results. In economic terms, UK firms adjust their leverage towards the target at a speed ranging between 0.425 and 0.434 . German firms have a relatively higher speed of adjustment, in the range of $0.455-0.495$. French firms appear to adjust towards their target leverage the most quickly: their estimated adjustment speed varies between 0.442 and 0.517 .

Empirically, our estimated speeds of adjustment are strongly consistent with the tradeoff theory's prediction that firms should adjust towards target leverage actively and frequently. With an adjustment speed of above 0.40, UK, German and French firms make full

\footnotetext{
${ }^{16}$ Note that if the relations between leverage and its determinants are inconsistent with the trade-off theory then target leverage is not well-defined, at least empirically, and so testing adjustment towards target leverage is likely to capture mechanical mean reversion behaviours (see Chang and Dasgupta, 2009).
} 
adjustment towards their target leverage in less than two and a half years. Further, this adjustment speed range is relatively quicker than the previous evidence documented in the literature. Antoniou et al. (2008), for example, employ a one-stage procedure to estimate the partial adjustment model analogous to (2) and report that French firms adjust towards the target the most quickly at a speed of 0.40 , followed by UK firms (0.32) and German firms (0.24). Thus, their estimated adjustment speeds are clearly slower than ours. Further, unlike Antoniou et al. (2008), we find that German firms adjust towards target leverage at a quicker speed than do UK firms. ${ }^{17}$ Our finding suggests that thanks to closer banking relationships, German and French firms may face lower adjustment costs and, therefore, find it easier to borrow or retire debt than their UK counterparts. Consequently, these firms may undertake faster leverage adjustments than firms in a market-based economy such as the UK. Finally, compared to previous US studies, we show that firms in the UK, Germany and France have considerably faster speeds of leverage adjustment. Fama and French (2002) show that US firms have slow adjustment speeds, ranging between $7-10 \%$ for dividend payers and $15-18 \%$ for non-payers. Byoun (2008), however, reports significantly faster speeds of adjustment in the range of 0.22-0.32 for a more recent and comprehensive sample of US firms. Flannery and Rangan (2006) and Antoniou et al. (2008) also show that US firms adjust towards their target leverage at a speed of more than 0.30, which is again slower than the speed with which the European firms in our sample undertake leverage adjustment.

In sum, we find that the estimated speeds of adjustment for our sample of UK, German and French firms are statistically and economically significant, which is strongly supportive of the trade-off theory.

\subsection{Results for the Error Correction Model}

Table 4 reports the estimation results for the error correction model of leverage specified by Equation (5). As in Table 3, Columns (1)-(3), (4)-(6) and (7)-(9) contain the results for firms in the UK, Germany and France, respectively. We adopt the AHIV estimator in Columns (1), (4) and (7), the GMM estimator in Columns (2), (5) and (8), and the SYSGMM estimator in Columns (3), (6) and (9). We report the statistics for the AR2 and

\footnotetext{
${ }^{17}$ There are two potential reasons why our results differ from Antoniou et al. (2008). First, we adopt a two-stage estimation procedure in which we first estimate target leverage in (3) before estimating the partial adjustment model in (2), while Antoniou et al. (2008) substitute (3) into (2) and estimate the resulting model in one stage. Second, Antoniou et al. (2008) examine a sample of UK, German and French firms over a relatively short period 1987-2000, which is a subset of the longer sample period between 1980 and 2007 used in our paper.
} 
Sargan tests as well as the statistics for the F-test under the null that the coefficients on $T L C_{i t}$ and $L E C M_{i t}$ are equal.

[Insert Table 4 about here]

In terms of model specification, the AR2 test results reveal that no models suffer from the problem of second-order serial correlation. However, the Sargan test is rejected at the $1 \%$ significance level in the GMM and SYSGMM models for UK firms, suggesting the corresponding estimation results may contain an over-identification bias and, thus, they should be treated with caution. As in Table 3, the AHIV estimates of the speeds of adjustment (i.e., the coefficients on $T L C_{i t}$ and $L E C M_{i t}$ ) appear to be downward biased compared to the GMM and SYSGMM estimates, which are theoretically more consistent and efficient. Hence, the following discussions will be focused on the GMM and SYSGMM estimation results.

The results show that the coefficients on target leverage change, $T L C_{i t}$, and the past deviation from target leverage, $L E C M_{i t}$, are both statistically and economically significant. By definition, the deviation from target leverage, $T L D_{i t}$, consists of the change in target leverage, $T L C_{i t}$, and the deviation from target leverage in the last accounting period, $L E C M_{i t}$; our results reveal that both of these factors have significant effects on firms' dynamic leverage adjustment towards the target. Further, these effects are significantly differential as the F-test is rejected at the $1 \%$ significance level. Specifically, the speed of adjustment corresponding to target leverage change is significantly faster than the speed corresponding to the past deviation from target leverage. UK firms adjust towards their target leverage in response to any changes in such target at a speed ranging between 0.759 and 0.776 . Firms in Germany and France make even more rapid adjustment in response to any movements towards target leverage; their respective adjustment speeds are estimated at $0.844-0.863$ and 0.931-0.933. On the contrary, firms undertake leverage adjustment at a much more moderate speed in response to the past deviation from the target; the adjustment speed is in the range of 0.390-0.397 for UK firms, $0.428-0.454$ for German firms and $0.439-0.440$ for French firms.

In sum, the results for the error correction model suggest that firms in the UK, Germany and France undertake dynamic but otherwise asymmetric adjustment towards target leverage. Firms react the most strongly to target leverage change with the corresponding speed of adjustment ranging between 0.776 and 0.933 . However, the speed of adjustment corresponding to the past deviation from target leverage is much slower, ranging from 0.390 to 0.454 . This pattern is consistent across firms in our sample countries. In terms of methodology, our finding highlights the advantage of employing the error correction model 
as a more general specification over the simple partial adjustment model in studying firms' dynamic adjustment towards target leverage. Finally, our results provide further support for the trade-off theory as we show that UK, German and French firms react strongly and actively to changes in and (past) deviations from target leverage when making adjustment towards such target.

\subsection{Results for the Pecking Order Theory}

Table 5 reports the estimation results for the pecking order model specified by Equation (8). Columns (1), (2) and (3) contain the results for UK, German and French firms, respectively. As mentioned, all models are static and therefore are estimated using the fixedeffects estimator.

[Insert Table 5 about here]

An overall examination of the results suggests that these models have a very low explanatory power with their respective R-squared varying between 0.061 and 0.106 . The constant term is insignificant in all models as predicted by the pecking order model. However, the estimated coefficient on the financing deficit/surplus variable, $\beta$, is statistically significant but relatively small in magnitude. For firms in the UK and France, this coefficient is estimated at 0.171 and 0.135 , respectively, suggesting a weak economic relation between these firms' financing deficit (surplus) and changes in debt levels. The highest coefficient estimate is 0.424 in Column (2), suggesting German firms offset nearly a half of their financing deficit (surplus) with debt policies. This latter finding is weakly consistent with the argument that firms in bank-based economies (e.g., Germany) face more information problems and should follow the pecking order style of financing more closely than firms in market-based economies (e.g., the UK).

More importantly, however, the F-test results show that the coefficient on the financing deficit/surplus variable, $\beta$, is statistically less than unity at the $1 \%$ significance level in all models. This finding is not in line with the second rung of the pecking order of financing, which requires that not only the constant term equal zero and but also $\beta$ equal unity. Finally, our empirical results are in contrast with the original US evidence by ShyamSunder and Myers (1999), but are consistent with recent US and international evidence against the pecking order theory (e.g., Flannery and Rangan, 2006; Seifert and Gonenc, 2008). 


\subsection{Results for Augmented Partial Adjustment and Error Correction Models}

In Table 6, we report the results for the augmented partial adjustment model of leverage based on (10) that captures the predictions of both the trade-off and pecking order theories. In constructing this table, we employ the same format used in Tables 3 and 4. As in Table 5, we report the F-test statistics under the null that the coefficient on the financing deficit/surplus variable is equal to unity.

\section{[Insert Table 6 about here]}

An overall examination of the diagnostic tests suggest that all the models are wellspecified and adopt valid instruments with the only exception being the GMM and SYSGMM models for UK firms where the Sargan test is rejected at the $1 \%$ significance level. As in Table 3, the AHIV estimates of the adjustment speed appear to carry a small downward bias, compared to the GMM and SYSGMM estimates. Hence, in what follows, we will focus our discussions on the latter estimates.

The results show that the trade-off theory clearly outperforms the pecking order theory in explaining corporate capital structure in the UK, Germany and France. The presence of the financing deficit/surplus variable does not affect the statistical and economic significance of the estimated speed of adjustment, which is still very fast, varying in the range between 0.405 and 0.514 . Note that these estimates are broadly similar to those estimated for the stand-alone partial adjustment model without the financing deficit/surplus variable (see Table 3). On the other hand, the coefficient on the financing deficit/surplus variable is significantly less than unity as revealed by the F-test. Specifically, this coefficient varies between 0.115 and 0.145 for UK firms and between 0.251 and 0.271 for German firms. Note that these estimates are slightly smaller than those estimated for the pecking order model in Table 5. Finally, for French firms, this coefficient even becomes insignificant in both statistical and economic terms. These findings suggest that in the present nested framework, the pecking order theory is dominated by the trade-off theory such that the former theory's relevant coefficient decreases in magnitude. In sum, the results for the augmented partial adjustment model are strongly favourable to the trade-off theory.

In Table 7, we report the estimation results for our most general model specification, namely the augmented error correction model of leverage that captures the pecking order theory's prediction. Overall, the results for this augmented error correction model are consistent with the trade-off theory but inconsistent with the pecking order theory. The two speeds of adjustment, i.e., the coefficients on $T L C_{i t}$ and $L E C M_{i t}$, are statistically and economically significant; they are unaffected by the presence of the financing deficit/surplus 
variable. Furthermore, they have the same magnitude as those estimated for the stand-alone error correction model in Table 4. Finally, the coefficient on the financing deficit/surplus variable is statistically insignificant for French firms and economically insignificant (less than unity) for UK and German firms.

\section{[Insert Table 7 about here]}

In summary, our augmented partial adjustment and error correction models provide consistent and strong support for the trade-off theory but little support for the pecking order theory. Although the financing/surplus deficit variable is significant for UK and German firms, the evidence does not suggest that these firms rely mainly on debt finance to offset their financing deficit/surplus as predicted by the pecking order theory. Our finding clearly shows that in nested empirical models, the trade-off theory explains firms' financing decisions better than the pecking order theory.

\subsection{Robustness Checks}

Thus far in our paper, we have used a market-based measure of leverage, which is consistent with the trade-off view and is adopted in many previous empirical studies (e.g., Titman and Wessels, 1988; Welch, 2004). However, some studies argue that managers in practice often prefer using book-based measures of leverage (Myers, 1984; Shyam-Sunder and Myers, 1999). Hence, in this subsection, we examine the robustness of our results to an alternative measure of leverage, namely book leverage, defined as the ratio of the book value of total debt to the book value of total assets. We follow the same estimation procedure detailed in Section 2.1. We report our first-stage regression results for the model of target leverage in Table 8 and second-stage results for the augmented error correction model in Table 9.

[Insert Table 8 and Table 9 about here]

The results for book leverage reported in Table 8 are slightly less significant than those for market leverage reported in Table 2. In particular, growth opportunities now become insignificant in Columns (2) and (3) while carry a positive sign in Column (1). The latter finding is inconsistent with our results for market leverage, but is, nevertheless, in line with the trade-off theory. The remaining variables are generally significant and have the expected signs, which is consistent with our results for market leverage.

The results in Table 9 show that the speeds of adjustment still maintain their statistical and economic significance; firms react significantly differently in response to changes in or deviations from target (book) leverage. The coefficient on the financing deficit/surplus variable is significant but considerably less than unity. These results are qualitatively similar 
to those obtained using market leverage in the previous sections. Hence, the main finding of the paper is robust to the choice of the leverage measure.

\section{Conclusions}

In this paper, we have examined the trade-off and pecking order theories of capital structure using new and unifying empirical models. Our paper has made at least three contributions to the literature. First, we have used an error correction model of leverage that captures changes in target leverage as well as past deviations from such target as key drivers of firms' dynamic leverage adjustment. Second, in our two-step estimation procedure, we have employed advanced and appropriate econometric methods to estimate the dynamic, partial adjustment and error correction models of leverage, thus providing more consistent and efficient estimates of the adjustment speeds. Third, our paper has also conducted one of the first empirical tests of both the trade-off and pecking order theories using an international dataset of UK, German and French firms.

Our results provide strong evidence for the trade-off theory as we find that UK, German and French firms adjust towards their target leverage relatively quickly in both the partial adjustment and error correction models. In particular, using the latter framework, we reveal that target leverage change has a significant impact on firms' dynamic adjustment behaviours. Firms in our sample countries react the most strongly to target leverage change but respond much more slowly to past deviations from target leverage. This finding has clearly demonstrated the advantage of the error correction model, a generalised version of the partial adjustment model, in studying firms' dynamic adjustment behaviours in particular and improving our understanding of corporate capital structure in general.

Finally, we show that UK, German and French firms do not closely follow the pecking order theory's prediction. Specifically, these firms only use debt to offset a small fraction of their financing deficit or surplus, which is inconsistent with the pecking order theory. More importantly, in specifications nesting the trade-off and pecking order theories, the former theory explains firms' financing decisions better than the latter theory. In sum, our results consistently show that trade-off considerations are of first-order importance to UK, German and French firms, which undertake dynamic adjustment towards target leverage in an active and rapid manner. 


\section{Acknowledgements}

We would like to thank an anonymous referee, Dan Coffey, Deborah Lucas, Evgeny Lyandres, Kevin T. Reilly, Yongcheol Shin and Mark Taylor (editor) for their helpful comments and suggestions. Partial financial support from the ESRC (grant No. RES-000-22$3161)$ is gratefully acknowledged. The usual disclaimer applies. 


\section{References}

Anderson, T.W., Hsiao, C., 1982. Formulation and Estimation of Dynamic Models Using Panel Data. Journal of Econometrics 18, 47-82.

Antoniou, A., Guney, Y., Paudyal, K., 2008. The Determinants of Capital Structure: Capital Market Oriented versus Bank Oriented Institutions. Journal of Financial and Quantitative Analysis 43, 59-92.

Arellano, M., Bond, S.R., 1991. Some Tests of Specification for Panel Data: Monte Carlo Evidence and an Application to Employment Equations. Review of Economic Studies $58,227-297$.

Baker, M., Wurgler, J., 2002. Market Timing and Capital Structure. Journal of Finance 57, 132.

Baltagi, B. H., 2008. Econometric Analysis of Panel Data. John Wiley and Sons, West Sussex.

Bennett, M., Donnelly, R., 1993. The Determinants of Capital Structure: Some UK Evidence. British Accounting Review 25, 43-59.

Bevan, A.A., Danbolt, J., 2002. Capital Structure and its Determinants in the UK - A Decompositional Analysis. Applied Financial Economics 12, 159-170.

Bevan, A.A., Danbolt, J., 2004. Testing for Inconsistencies in the Estimation of UK Capital Structure Determinants. Applied Financial Economics 14, pp. 55-66.

Blundell, R.W., Bond, S.R., 1998. Initial Conditions and Moment Restrictions in Dynamic Panel Data Models. Journal of Econometrics 87, 115-143.

Byoun, S., 2008. How and When Do Firms Adjust Their Capital Structures toward Targets?. Journal of Finance 63, 3069-3096.

Bradley, M., Jarrell, G.A., Kim, E.H., 1984. On the Existence of an Optimal Capital Structure: Theory and Evidence. Journal of Finance 39, 857-878.

Chang, X., Dasgupta, S., 2009. Target Behavior and Financing: How Conclusive is the Evidence. Journal of Finance 64, 1767-1796.

Chirinko, R.S., Singha, A.R., 2000. Testing Static Trade-off Theory against Pecking Order Models of Capital Structure: A Critical Comment. Journal of Financial Economics 58, 417-425.

de Jong, A., Kabir, R., Nguyen, T.T., 2008. Capital Structure around the World: The Roles of Firm- and Country-Specific Determinants. Journal of Banking and Finance 32, 19541969. 
de Jong, A., Verbeek, M., Verwijmeren, P., 2010. Testing the Pecking Order Theory: The Impact of Financing Surpluses and Large Financing Deficits. Financial Management $39,733-756$.

de Jong, A., Verbeek, M., Verwijmeren, P., 2011. Firms' Debt-equity Decisions When the Static Tradeoff Theory and the Pecking Order Theory Disagree. Journal of Banking and Finance 35, 1303-1314.

Dang, V.A., Kim, M., Shin, Y., 2009. Asymmetric Capital Structure Adjustments: New Evidence from Dynamic Panel Threshold Models, Working paper, Manchester Business School.

Dang, V.A., 2010. Testing the Trade-off and Pecking Order Theories: A Dynamic Panel Framework, Working paper, Manchester Business School.

Dang, V.A., 2011. Leverage, Debt Maturity and Firm Investment: An Empirical Analysis. Journal of Business Finance and Accounting 38, 235-258.

DeAngelo, H., Masulis, R., 1980. Optimal Capital Structure under Corporate and Personal Taxation. Journal of Financial Economics 8, 3-29.

Fama, E.F., French, K.R., 2002. Testing Trade-Off and Pecking Order Predictions about Dividends and Debt. Review of Financial Studies 15, 1-33.

Fama, E.F., French, K.R., 2005. Financing Decisions: Who Issues Stock? Journal of Financial Economics 76, 549-582.

Fama, E.F., MacBeth, J.D., 1973. Risk, Return, and Equilibrium: Empirical Tests. Journal of Political Economy 81, 607-636.

Fischer, E.O., Heinkel, R., Zechner, J., 1989. Dynamic Capital Structure Choice: Theory and Tests. Journal of Finance 44, 19-40.

Flannery, M.J., Rangan, K.P., 2006. Partial Adjustment toward Target Capital Structures. Journal of Financial Economics 79, 469-506.

Frank, M.Z., \& Goyal, V.K., 2007. Trade-off and Pecking Order Theories of Debt. in Eckbo, B.E. (ed). Handbook of Corporate Finance: Empirical Corporate Finance. North Holland Handbooks of Finance, Elsevier Science.

Frank, M., \& Goyal, V.K., 2009. Capital Structure Decisions: Which Factors Are Reliably Important? Financial Management 38, 1-37.

Harris, M., Raviv, A., 1991. The Theory of Capital Structure. Journal of Finance 46, 297-356.

Heinkel. R., 1982. A Theory of Capital Structure Relevance Under Imperfect Information. Journal of Finance 37, 1411-1150.

Hennessy, C.A., Whited, T. M., 2006. Debt Dynamics. Journal of Finance 60, 1129-1165. 
Huang, R., Ritter, J.R., 2009. Testing Theories of Capital Structure and Estimating the Speed of Adjustment. Journal of Financial and Quantitative Analysis 44, 237-271.

Jensen, M., Meckling, W., 1976. Theory of the Firm: Managerial Behavior, Agency Costs and Ownership Structure. Journal of Financial Economics 3, 305-360.

Jensen, M., 1986. Agency Costs of Free Cash Flow, Corporate Finance and Takeovers. American Economic Review 76, 323-339.

Kraus, A., Litzenberger, R.H., 1973. A State-Preference Model of Optimal Financial Leverage. Journal of Finance 28, 911-922.

Leary, M.T., Roberts, M.R., 2005. Do Firms Rebalance Their Capital Structures. Journal of Finance 60, 2575-2619.

Leland, H.E., Pyle, D.H., 1977. Informational Asymmetries, Financial Structure and Financial Intermediation. Journal of Finance 32, 371-387.

Lemmon, M.L., Roberts, M.R., \& Zender, J.F., 2008. Back to the Beginning: Persistence and the Cross-Section of Corporate Capital Structure. Journal of Finance 63, 1575-1608.

Lemmon, M.L., Zender, J.F., 2010. Debt Capacity and Tests of Capital Structure Theories. Journal of Financial and Quantitative Analysis 45, 1161-1187.

Maddala, 2001. Introduction to Econometrics. $3^{\text {rd }}$ Edition, John Wiley and Sons.

Modigliani, F., Miller, M.H., 1958. The Cost of Capital, Corporate Finance and the Theory of Investment. American Economic Review 49, 261-297.

Modigliani, F., Miller, M.H., 1963. Taxes and the Cost of Capital: A Correction. American Economic Review 53, 433-43.

Myers, S.C., 1977. Determinants of Corporate Borrowing. Journal of Financial Economics 5, $145-175$.

Myers, S.C., 1984. The Capital Structure Puzzle. Journal of Finance 34, 575-592.

Myers, S.C., 2001. Capital Structure. Journal of Economic Perspectives 15, 81-102.

Myers, S.C., Majluf, N.S., 1984. Corporate Financing and Investments Decisions When Firms Have Information That Investors Do Not Have. Journal of Financial Economics $13,187-221$.

Nickell, S.J., 1981. Biases in Dynamic Models with Fixed Effects. Econometrica 49, 14171426.

Ozkan, A., 2001. Determinants of Capital Structure and Adjustment to Long Run Target: Evidence from UK Company Panel Data. Journal of Business Finance and Accounting 28, 175-198. 
Rajan, R.G., Zingales, L., 1995. What Do We Know about Capital Structure? Some Evidence from International Data. Journal of Finance 50, 1421-1461.

Ross, S., 1977. The Determination of Financial Structure: The Incentive Signaling Approach. Bell Journal of Economics 8, 23-40.

Seifert, B., Gonenc, H., 2008. The International Evidence on the Pecking Order Hypothesis. Journal of Multinational Financial Management 18, 244-260.

Shyam-Sunder, L., Myers, S., 1999. Testing Static Trade-off against Pecking Order Models of Capital Structure. Journal of Financial Economics 51, 219-244.

Strebulaev, I.A., 2007. Do Tests of Capital Structure Theory Mean What They Say. Journal of Finance 62, 1747-1787.

Titman, S., Wessels, R., 1988. The Determinants of Capital Structure Choice. Journal of Finance 43, 1-19.

Wald, J.K., 1999. How Firm Characteristics Affect Capital Structure: An International Comparison. Journal of Financial Research 22, 161-187.

Watson, R., Wilson, N., 2002. Small and Medium Size Enterprise: A Note on Some of the Implications of a Pecking Order. Journal of Business Finance and Accounting 29, 557-578.

Welch, I., 2004. Capital Structure and Stock Returns. Journal of Political Economy 112, 10631. 
Table 1. Variable Definitions \& Descriptive Statistics

\begin{tabular}{|c|c|c|c|c|c|}
\hline \multicolumn{6}{|c|}{ Panel A: Descriptive Statistics for UK Firms } \\
\hline Variable & Obs & Mean & Std. Dev. & Min & Max \\
\hline Market leverage & 11,635 & 0.191 & 0.195 & 0.000 & 0.824 \\
\hline Collateral value of assets & 11,635 & 0.296 & 0.247 & 0.000 & 0.933 \\
\hline Non-debt tax shields & 11,635 & 0.049 & 0.040 & 0.000 & 0.226 \\
\hline Profitability & 11,635 & 0.009 & 0.252 & -1.647 & 0.379 \\
\hline Growth opportunities & 11,635 & 1.586 & 1.757 & 0.260 & 12.781 \\
\hline Size & 11,635 & 10.094 & 2.125 & 4.705 & 15.273 \\
\hline Cash flow deficit & 11,635 & 0.036 & 0.229 & -0.478 & 1.759 \\
\hline \multicolumn{6}{|c|}{ Panel B: Descriptive Statistics for German Firms } \\
\hline Variable & Obs & Mean & Std. Dev. & Min & Max \\
\hline Market leverage & 3,640 & 0.278 & 0.250 & 0.000 & 0.875 \\
\hline Collateral value of assets & 3,640 & 0.249 & 0.186 & 0.000 & 0.874 \\
\hline Non-debt tax shields & 3,640 & 0.060 & 0.049 & 0.000 & 0.333 \\
\hline Profitability & 3,640 & -0.002 & 0.156 & -0.885 & 0.363 \\
\hline Growth opportunities & 3,640 & 1.091 & 0.997 & 0.166 & 8.356 \\
\hline Size & 3,640 & 11.779 & 2.016 & 6.412 & 17.558 \\
\hline Cash flow deficit & 3,640 & 0.005 & 0.118 & -0.310 & 1.023 \\
\hline \multicolumn{6}{|c|}{ Panel C: Descriptive Statistics for French Firms } \\
\hline Variable & Obs & Mean & Std. Dev. & Min & Max \\
\hline Market leverage & 2,503 & 0.294 & 0.236 & 0.000 & 0.912 \\
\hline Collateral value of assets & 2,503 & 0.194 & 0.159 & 0.003 & 0.796 \\
\hline Non-debt tax shields & 2,503 & 0.055 & 0.042 & 0.002 & 0.247 \\
\hline Profitability & 2,503 & 0.028 & 0.114 & -0.553 & 0.343 \\
\hline Growth opportunities & 2,503 & 1.095 & 0.889 & 0.137 & 6.488 \\
\hline Size & 2,503 & 11.968 & 2.200 & 6.703 & 16.778 \\
\hline Cash flow deficit & 2,503 & 0.010 & 0.105 & -0.238 & 0.755 \\
\hline
\end{tabular}

Notes: This table presents the descriptive statistics, including the mean, standard deviation (Std.Dev.), minimum (Min) and maximum (Max), for the variables under consideration in the paper. Panel A, B and C reports the statistics for firms in the UK, Germany and France, respectively. Market leverage is the ratio of total debt divided by the market value of equity plus the book value of debt. Collateral value of assets is the ratio of fixed assets to total assets. Profitability is the ratio of EBITDA to total assets. Non-debt tax shields are the ratio of depreciation to total assets. Growth opportunities are the market value of equity plus the book value of debt to total assets. Size is the log of total assets in 1980 price. Cash flow deficit is defined as $(-C F+I+D I V+\Delta C)$, where $C F$ denotes Cash flow after tax and interest including change in working capital (i.e., $C F=$ Cash flow from Operating activities less Investment return and servicing of finance and Taxation). $I$ is Net investment (i.e. $I=$ Capital Expenditures plus Acquisitions and Disposals). $D I V$ is equity dividends paid. $\Delta C$ is net change in cash including change in working capital. Obs. denotes the number of observations available. 
Table 2. Target Leverage Estimations for Market Leverage

\begin{tabular}{lccc}
\hline Variables & UK & Germany & France \\
& $(1)$ & $(2)$ & $(3)$ \\
\hline Collateral value of assets & $0.181^{* * *}$ & $0.386^{* * *}$ & $0.261^{* * *}$ \\
Non-debt tax shields & $(0.013)$ & $(0.036)$ & $(0.048)$ \\
& $0.314^{* * *}$ & 0.102 & $0.327^{* * *}$ \\
Profitability & $(0.049)$ & $(0.079)$ & $(0.094)$ \\
& $-0.132^{* * *}$ & $-0.242^{* * *}$ & $-0.302^{* * *}$ \\
Growth opportunities & $(0.008)$ & $(0.024)$ & $(0.035)$ \\
& $-0.019^{* * *}$ & $-0.038^{* * *}$ & $-0.052^{* * *}$ \\
Size & $(0.001)$ & $(0.003)$ & $(0.004)$ \\
& $0.040^{* * *}$ & $0.068^{* * *}$ & $0.035^{* * *}$ \\
Constant & $(0.002)$ & $(0.006)$ & $(0.005)$ \\
& $-0.250^{* * *}$ & $-0.578^{* * *}$ & $-0.130^{*}$ \\
\hline Estimators & $(0.024)$ & $(0.068)$ & $(0.068)$ \\
Observations & $F E$ & $F E$ & $F E$ \\
$R$-squared & 11,635 & 3,640 & 2,503 \\
Number of Firms & 0.118 & 0.168 & 0.189 \\
\hline
\end{tabular}

Notes: This table reports the regression results for target leverage modelled by Equation (3), as follows:

$$
D_{i t}^{*}=\boldsymbol{\beta}^{\prime} \mathbf{x}+w_{i t},
$$

where $\mathbf{x}$ is a vector of five firm characteristics, namely collateral value of assets, non-debt tax shields, profitability, growth opportunities and firm size, and $\boldsymbol{\beta}$ is the vector of the parameters. $F E$ denotes the (withingroup) fixed-effects estimator. Robust standard errors of coefficients are reported in parentheses. *, ** and *** indicate the coefficient significant at the $10 \%, 5 \%$ and $1 \%$ levels, respectively. See Table 1 for variable definitions. 
Table 3. Testing the Trade-off Theory Using the Partial Adjustment Model

\begin{tabular}{|c|c|c|c|c|c|c|c|c|c|}
\hline \multirow[b]{2}{*}{ Variables } & \multicolumn{3}{|c|}{ UK } & \multicolumn{3}{|c|}{ Germany } & \multicolumn{3}{|c|}{ France } \\
\hline & (1) & (2) & (3) & (4) & $(5)$ & $(6)$ & (7) & $(8)$ & (9) \\
\hline \multirow[t]{2}{*}{$T L D$} & $0.425 * * *$ & $0.433 * * *$ & $0.434 * * *$ & $0.455^{* * *}$ & $0.483^{* * *}$ & $0.495^{* * *}$ & $0.442 * * *$ & $0.517 * * *$ & $0.512^{* * *}$ \\
\hline & $(0.025)$ & $(0.014)$ & $(0.015)$ & $(0.046)$ & $(0.027)$ & $(0.027)$ & $(0.047)$ & $(0.029)$ & $(0.031)$ \\
\hline \multirow[t]{2}{*}{ Constant } & $0.001 *$ & $0.002 * * *$ & $0.004 * * *$ & $-0.003 * *$ & $-0.003 * *$ & 0.001 & $-0.007 * * *$ & $-0.006^{* * *}$ & 0.000 \\
\hline & $(0.001)$ & $(0.001)$ & $(0.001)$ & $(0.001)$ & $(0.001)$ & $(0.001)$ & $(0.001)$ & $(0.001)$ & $(0.001)$ \\
\hline Estimators & $A H I V$ & $G M M$ & SYSMM & $A H I V$ & $G M M$ & SYSMM & $A H I V$ & $G M M$ & SYSMM \\
\hline Observations & 8,819 & 8,819 & 10,209 & 2,668 & 2,668 & 3,147 & 1,841 & 1,841 & 2,167 \\
\hline Number of firms & 1,340 & 1,340 & 1,340 & 446 & 446 & 446 & 316 & 316 & 316 \\
\hline$A R 2$ test & -1.381 & -1.376 & -1.373 & 0.516 & 0.506 & 0.529 & 0.780 & 0.669 & 0.747 \\
\hline Sargan test & - & $177.4^{* * *}$ & $245.1 * * *$ & - & 93.35 & $140.0 * *$ & - & 96.99 & 123.4 \\
\hline
\end{tabular}

Notes: This table reports the estimation results for the partial adjustment model of leverage specified by Equation (2), as follows:

$\Delta D_{i t}=\alpha+\lambda T L D_{i t}+u_{i t}$,

where $\Delta D_{i t}$ is market leverage change. $T L D_{i t}$ stands for the deviation of lagged leverage from target leverage. See Table 2 for target leverage estimations. $A H I V$ denotes the Anderson and Hsiao's (1982) instrumental variable estimator. GMM and SYSGMM denote Arellano and Bond's (1991) and Blundell and Bond's (1998) estimators, respectively. $A R 2$ test is a test for second-order serial correlation, under the null of no serial correlation. Sargan test is a test for over-identifying restrictions under the null of valid instruments. Robust standard errors of coefficients are reported in parentheses. $*, * *$ and $* * *$ indicate the coefficient significant at the $10 \%, 5 \%$ and $1 \%$ levels, respectively. 
Table 4. Testing the Trade-off Theory Using the Error Correction Model

\begin{tabular}{|c|c|c|c|c|c|c|c|c|c|}
\hline \multirow[b]{2}{*}{ Variables } & \multicolumn{3}{|c|}{ UK } & \multicolumn{3}{|c|}{ Germany } & \multicolumn{3}{|c|}{ France } \\
\hline & $(1)$ & $(2)$ & (3) & $(4)$ & $(5)$ & $(6)$ & $(7)$ & $(8)$ & (9) \\
\hline \multirow[t]{2}{*}{$T L C$} & $0.719^{* * *}$ & $0.776^{* * *}$ & $0.759 * * *$ & $0.681 * * *$ & $0.844 * * *$ & $0.863^{* * *}$ & $0.777 * * *$ & $0.931 * * *$ & $0.933 * * *$ \\
\hline & $(0.050)$ & $(0.044)$ & $(0.042)$ & $(0.072)$ & $(0.064)$ & $(0.061)$ & $(0.082)$ & $(0.067)$ & $(0.071)$ \\
\hline \multirow[t]{2}{*}{$L E C M$} & $0.335^{* * *}$ & $0.390 * * *$ & $0.397 * * *$ & $0.380 * * *$ & $0.428 * * *$ & $0.454^{* * *}$ & $0.299 * * *$ & $0.440 * * *$ & $0.439 * * *$ \\
\hline & $(0.028)$ & $(0.014)$ & $(0.015)$ & $(0.054)$ & $(0.025)$ & $(0.026)$ & $(0.059)$ & $(0.030)$ & $(0.032)$ \\
\hline \multirow[t]{2}{*}{ Constant } & $0.001 * *$ & $0.002 * * *$ & $0.004 * * *$ & $-0.003 * *$ & $-0.003 * *$ & 0.002 & $-0.005 * * *$ & $-0.005 * * *$ & -0.001 \\
\hline & $(0.001)$ & $(0.001)$ & $(0.001)$ & $(0.001)$ & $(0.001)$ & $(0.001)$ & $(0.001)$ & $(0.001)$ & $(0.001)$ \\
\hline Estimators & $A H I V$ & $G M M$ & SYSGMM & AHIV & $G M M$ & SYSGMM & $A H I V$ & $G M M$ & SYSGMN \\
\hline Observations & 8819 & 8819 & 10209 & 2668 & 2668 & 3147 & 1841 & 1841 & 2167 \\
\hline Number of firms & 1340 & 1340 & 1340 & 446 & 446 & 446 & 316 & 316 & 316 \\
\hline$A R 2$ & -1.248 & -1.336 & -1.344 & 0.952 & 1.090 & 1.100 & 1.117 & 1.021 & 1.074 \\
\hline Sargan test & - & $317.9 * * *$ & $411.4 * * *$ & - & 170.7 & 220.3 & - & 165.0 & 179.6 \\
\hline$F$-test & $49.70 * * *$ & $70.82 * * *$ & $67.54 * * *$ & $24.08^{* * *}$ & $46.56^{* * *}$ & $39.41 * * *$ & $12.83^{* * *}$ & $41.92 * * *$ & $41.74 * * *$ \\
\hline
\end{tabular}

Notes: This table reports the estimation results for the error correction model of leverage specified by (6), as follows:

$$
\Delta D_{i t}=\alpha+\lambda T L C_{i t}+\gamma L E C M_{i t}+u_{i t},
$$

where $\Delta D_{i t}$ is market leverage change. The independent variables are $T L C_{i t}$ and $L C E M_{i t}$, which denote target leverage change and (lagged) deviation from target leverage (i.e., lagged error correction term), respectively. See Table 2 for target leverage estimations. AHIV denotes the Anderson and Hsiao's (1982) instrumental variable estimator. GMM and SYSGMM denote Arellano and Bond's (1991) and Blundell and Bond's (1998) estimators, respectively. AR2 test is a test for second-order serial correlation, under the null of no serial correlation. Sargan test is a test for over-identifying restrictions under the null of valid instruments. $F$-test is a test for the difference between the coefficients $T L C_{i t}$ and $L E C M_{i t}$, under the null of no difference, $T L C_{i t}=L E C M_{i t}$. Robust standard errors of coefficients are reported in parentheses. $*$, ** and $* * *$ indicate the coefficient significant at the $10 \%, 5 \%$ and $1 \%$ levels, respectively. 
Table 5. Testing the Pecking Order Theory

\begin{tabular}{lccc}
\hline Variables & UK & Germany & France \\
\hline$D E F$ & $(1)$ & $(2)$ & $(3)$ \\
& $0.171^{* * *}$ & $0.424^{* * *}$ & $0.135^{* * *}$ \\
Constant & $(0.007)$ & $(0.024)$ & $(0.031)$ \\
& 0.001 & -0.000 & -0.000 \\
Estimators & $(0.001)$ & $(0.002)$ & $(0.003)$ \\
Observations & $F E$ & $F E$ & $F E$ \\
$R$-squared & 10,209 & 3,147 & 2,167 \\
Number of firms & 0.061 & 0.106 & 0.010 \\
$F$-test & 1,340 & 446 & 316 \\
\hline
\end{tabular}

Notes: This table reports the estimation results for the pecking order model specified by Equation (8), as follows:

$$
\Delta D_{i t}=\alpha+\beta D E F_{i t}+\varepsilon_{i t}
$$

where $\Delta D_{i t}$ is market leverage change. $D E F_{i t}$ is the cash flow deficit variable, defined by Equation (9). $F E$ denotes the (within-group) fixed-effects estimator. $F$-test is the test for the null hypothesis that $\beta=1$. Standard errors of coefficients are reported in parentheses. *, ** and *** indicate the coefficient significant at the $10 \%$, $5 \%$ and $1 \%$ levels, respectively. 
Table 6. Testing the Trade-off and Pecking Order Theories Using the Augmented Partial Adjustment Model

\begin{tabular}{|c|c|c|c|c|c|c|c|c|c|}
\hline \multirow[b]{2}{*}{ Variables } & \multicolumn{3}{|c|}{ UK } & \multicolumn{3}{|c|}{ Germany } & \multicolumn{3}{|c|}{ France } \\
\hline & $(1)$ & (2) & (3) & (4) & $(5)$ & $(6)$ & $(7)$ & $(8)$ & (9) \\
\hline \multirow[t]{2}{*}{$T L D$} & $0.386^{* * *}$ & $0.405 * * *$ & $0.410^{* * *}$ & $0.402 * * *$ & $0.442 * * *$ & $0.457 * * *$ & $0.439 * * *$ & $0.514 * * *$ & $0.508 * * *$ \\
\hline & $(0.027)$ & $(0.014)$ & $(0.015)$ & $(0.048)$ & $(0.028)$ & $(0.027)$ & $(0.049)$ & $(0.033)$ & $(0.034)$ \\
\hline \multirow[t]{2}{*}{$D E F$} & $0.150 * * *$ & $0.145^{* * *}$ & $0.115^{* * *}$ & $0.298 * * *$ & $0.271 * * *$ & $0.251 * * *$ & 0.049 & 0.040 & 0.061 \\
\hline & $(0.012)$ & $(0.012)$ & $(0.009)$ & $(0.041)$ & $(0.039)$ & $(0.036)$ & $(0.085)$ & $(0.081)$ & $(0.067)$ \\
\hline \multirow[t]{2}{*}{ Constant } & $0.002 * * *$ & $0.003 * * *$ & 0.001 & $-0.004 * * *$ & $-0.003 * * *$ & 0.001 & $-0.006 * * *$ & $-0.006^{* * *}$ & -0.000 \\
\hline & $(0.001)$ & $(0.001)$ & $(0.001)$ & $(0.001)$ & $(0.001)$ & $(0.001)$ & $(0.001)$ & $(0.001)$ & $(0.001)$ \\
\hline Estimators & $A H I V$ & $G M M$ & SYSGMM & $A H I V$ & $G M M$ & SYSGMM & $A H I V$ & $G M M$ & SYSGMM \\
\hline Observations & 8,819 & 8,819 & 10,209 & 2,668 & 2,668 & 3,147 & 1,841 & 1,841 & 2,167 \\
\hline Number of firms & 1340 & 1340 & 1340 & 446 & 446 & 446 & 316 & 316 & 316 \\
\hline$A R 2$ & -1.501 & -1.511 & -1.450 & 0.334 & 0.329 & 0.373 & 0.899 & 0.778 & 0.880 \\
\hline Sargan test & - & $180.7 * * *$ & $242.9^{* * *}$ & - & 98.01 & 142.1 & - & 97.07 & 121.7 \\
\hline F-test & $4843.50 * * *$ & $5313.36^{* * *}$ & $9539.67 * * *$ & $290.34 * * *$ & $350.44 * * *$ & $438.98 * * *$ & $126.12 * * *$ & $139.51 * * *$ & $199.01 * * *$ \\
\hline
\end{tabular}

Notes: This table reports the estimation results for the augmented partial adjustment model of leverage that nests the pecking order theory specified by (10), as follows:

$$
\Delta D_{i t}=\alpha+\delta T L D_{i t}+\beta D E F_{i t}+u_{i t},
$$

where $\Delta D_{i t}$ is market leverage change. TLD it is the deviation of lagged leverage from target leverage. See Table 2 for target leverage estimations. $D E F_{i t}$ is the cash flow deficit variable, defined by Equation (9). AHIV denotes the Anderson and Hsiao's (1982) instrumental variable estimator. GMM and SYSGMM denote Arellano and Bond's (1991) and Blundell and Bond's (1998) estimators, respectively. AR2 test is a test for second-order serial correlation, under the null of no serial correlation. Sargan test is a test for over-identifying restrictions under the null of valid instruments. $F$-test is the test for the null hypothesis that $\beta=1$. Robust standard errors of coefficients are reported in parentheses. * ** and *** indicate the coefficient significant at the $10 \%, 5 \%$ and $1 \%$ levels, respectively. 
Table 7. Testing the Trade-off and Pecking Order Theories Using the Augmented Error Adjustment Model

\begin{tabular}{|c|c|c|c|c|c|c|c|c|c|}
\hline \multirow[b]{2}{*}{ Variables } & \multicolumn{3}{|c|}{ UK } & \multicolumn{3}{|c|}{ Germany } & \multicolumn{3}{|c|}{ France } \\
\hline & $(1)$ & $(2)$ & (3) & $(4)$ & $(5)$ & $(6)$ & $(7)$ & $(8)$ & (9) \\
\hline \multirow[t]{2}{*}{$T L C$} & $0.638 * * *$ & $0.719 * * *$ & $0.710 * * *$ & $0.586 * * *$ & $0.754 * * *$ & $0.776 * * *$ & $0.771 * * *$ & $0.923 * * *$ & $0.924 * * *$ \\
\hline & $(0.051)$ & $(0.041)$ & $(0.039)$ & $(0.072)$ & $(0.057)$ & $(0.054)$ & $(0.084)$ & $(0.069)$ & $(0.072)$ \\
\hline \multirow[t]{2}{*}{$L E C M$} & $0.308 * * *$ & $0.366^{* * *}$ & $0.377 * * *$ & $0.342 * * *$ & $0.395 * * *$ & $0.424 * * *$ & $0.298 * * *$ & $0.437 * * *$ & $0.436 * * *$ \\
\hline & $(0.029)$ & $(0.015)$ & $(0.015)$ & $(0.055)$ & $(0.027)$ & $(0.027)$ & $(0.060)$ & $(0.034)$ & $(0.035)$ \\
\hline \multirow[t]{2}{*}{$D E F$} & $0.153 * * *$ & $0.142 * * *$ & $0.112 * * *$ & $0.297 * * *$ & $0.272 * * *$ & $0.242 * * *$ & 0.054 & 0.048 & 0.061 \\
\hline & $(0.012)$ & $(0.011)$ & $(0.009)$ & $(0.041)$ & $(0.039)$ & $(0.034)$ & $(0.091)$ & $(0.083)$ & $(0.066)$ \\
\hline \multirow[t]{2}{*}{ Constant } & $0.002 * * *$ & $0.002 * * *$ & 0.001 & $-0.003 * * *$ & $-0.003 * * *$ & 0.002 & $-0.005 * * *$ & $-0.005 * * *$ & -0.001 \\
\hline & $(0.001)$ & $(0.001)$ & $(0.001)$ & $(0.001)$ & $(0.001)$ & $(0.001)$ & $(0.001)$ & $(0.001)$ & $(0.001)$ \\
\hline Observations & 8,819 & 8,819 & 10,209 & 2,668 & 2,668 & 3,147 & 1,841 & 1,841 & 2,167 \\
\hline Estimators & $A H I V$ & $G M M$ & SYSGMM & $A H I V$ & $G M M$ & SYSGMM & $A H I V$ & $G M M$ & SYSGMM \\
\hline Number of firms & 1,340 & 1,340 & 1,340 & 446 & 446 & 446 & 316 & 316 & 316 \\
\hline$A R 2$ test & -1.345 & -1.419 & -1.381 & 0.701 & 0.824 & 0.864 & 1.229 & 1.135 & 1.191 \\
\hline Sargan test & - & $299.4 * * *$ & $394.2 * * *$ & - & 173.2 & $223.2 *$ & - & 163.9 & 180.0 \\
\hline$F$-test 1 & $35.87 * * *$ & $62.74 * * *$ & $62.01 * * *$ & $8.88 * * *$ & $40.08 * * *$ & $40.76 * * *$ & $24.16^{* * *}$ & $46.54 * * *$ & $39.12 * * *$ \\
\hline$F$-test 2 & $4890.59^{* * *}$ & $5844.68^{* * *}$ & $10515.42 * * *$ & $290.11 * * *$ & $353.76^{* * *}$ & $510.54 * * *$ & $108.89^{* * *}$ & $130.65^{* * *}$ & $201.56 * * *$ \\
\hline
\end{tabular}

Notes: This table reports the estimation results for the augmented error correction model of leverage that nests the pecking order theory specified by Equation (11), as follows:

$$
\Delta D_{i t}=\alpha+\lambda T L C_{i t}+\gamma L E C M_{i t}+\beta D E F_{i t}+u_{i t}
$$

where $\Delta D_{i t}$ is market leverage change. $T L C_{i t}$ and $L E C M_{i t}$ denote target leverage change and (lagged) deviation from target leverage (i.e., lagged error correction term), respectively. Note that target leverage is estimated in Table 2. $D E F_{i t}$ is the cash flow deficit variable, defined by Equation (9). AHIV denotes the Anderson and Hsiao's (1982) instrumental variable estimator. GMM and SYSGMM denote Arellano and Bond's (1991) and Blundell and Bond's (1998) estimators, respectively. AR2 test is a test for second-order serial correlation, under the null of no serial correlation. Sargan test is a test for over-identifying restrictions under the null of valid instruments. $F$-test 1 is a test for the difference between the coefficients on $T L C_{i t}$ and $L E C M_{i t}$, under the null of no difference, $T L C_{i t}=L E C M_{i t} . F$-test 2 is the test for the null hypothesis that $\beta=1$. Robust standard errors of coefficients are reported in parentheses. * $* *$ and $* * *$ indicate the coefficient significant at the $10 \%, 5 \%$ and $1 \%$ levels, respectively. 
Table 8. Target Leverage Estimation for Book Leverage

\begin{tabular}{lccc}
\hline Variables & UK & Germany & France \\
\hline Collateral value of assets & $(1)$ & $(2)$ & $(3)$ \\
\hline Non-debt tax shields & $(0.175 * * *$ & $0.359 * * *$ & $0.113 * * *$ \\
& $0.348^{* * *}$ & $(0.026)$ & $(0.036)$ \\
Profitability & $(0.049)$ & -0.033 & -0.030 \\
& $-0.124 * * *$ & $-0.142 * * *$ & $-0.253 * * *$ \\
Growth & $(0.008)$ & $(0.018)$ & $(0.027)$ \\
& $0.008 * * *$ & -0.003 & -0.003 \\
Size & $(0.001)$ & $(0.002)$ & $(0.003)$ \\
& $0.023 * * *$ & $0.043 * * *$ & $0.028 * * *$ \\
Constant & $(0.002)$ & $(0.004)$ & $(0.004)$ \\
Number of Firms & $-0.129 * * *$ & $-0.378 * * *$ & $-0.110 * *$ \\
\hline Estimators & $(0.024)$ & $(0.049)$ & $(0.051)$ \\
\hline
\end{tabular}

Notes: This table reports the regression results for target (book) leverage modelled by Equation (3):

$$
D_{i t}^{*}=\boldsymbol{\beta}^{\prime} \mathbf{x}+w_{i t},
$$

where $\mathbf{x}$ is a vector of five firm characteristics, namely collateral value of assets, non-debt tax shields, profitability, growth opportunities and firm size, and $\boldsymbol{\beta}$ is the vector of the parameters. $F E$ denotes the (withingroup) fixed-effects estimator. Robust standard errors of coefficients are reported in parentheses. $*, * *$ and *** indicate the coefficient significant at the $10 \%, 5 \%$ and $1 \%$ levels, respectively. See Table 1 for variable definitions. 
Table 9. Testing the Trade-off and Pecking Order Theories Using the Augmented Error Correction Model of Book Leverage

\begin{tabular}{|c|c|c|c|c|c|c|c|c|c|}
\hline \multirow[b]{2}{*}{ Variables } & \multicolumn{3}{|c|}{$\mathbf{U K}$} & \multicolumn{3}{|c|}{ Germany } & \multicolumn{3}{|c|}{ France } \\
\hline & $(1)$ & (2) & (3) & (4) & $(5)$ & (6) & (7) & $(8)$ & (9) \\
\hline \multirow[t]{2}{*}{$T L C$} & $0.915 * * *$ & $0.877 * * *$ & $0.850 * * *$ & $0.520 * * *$ & $0.625 * * *$ & $0.722 * * *$ & $0.747 * * *$ & $0.829 * * *$ & $0.730 * * *$ \\
\hline & $(0.093)$ & $(0.075)$ & $(0.074)$ & $(0.119)$ & $(0.089)$ & $(0.086)$ & $(0.152)$ & $(0.119)$ & $(0.107)$ \\
\hline \multirow{2}{*}{$L E C M$} & $0.346^{* * *}$ & $0.376 * * *$ & $0.375 * * *$ & $0.267 * * *$ & $0.289 * * *$ & $0.302 * * *$ & $0.342 * * *$ & $0.314 * * *$ & $0.333 * * *$ \\
\hline & $(0.040)$ & $(0.023)$ & $(0.024)$ & $(0.054)$ & $(0.035)$ & $(0.034)$ & $(0.074)$ & $(0.050)$ & $(0.047)$ \\
\hline \multirow[t]{2}{*}{$D E F$} & $0.180 * * *$ & $0.175^{* * *}$ & $0.141 * * *$ & $0.306 * * *$ & $0.302 * * *$ & $0.280 * * *$ & $0.172 * *$ & $0.174 * *$ & $0.164 * * *$ \\
\hline & $(0.019)$ & $(0.019)$ & $(0.015)$ & $(0.033)$ & $(0.031)$ & $(0.028)$ & $(0.079)$ & $(0.078)$ & $(0.060)$ \\
\hline \multirow[t]{2}{*}{ Constant } & $0.003 * * *$ & $0.004 * * *$ & 0.000 & -0.000 & 0.000 & $0.003 * * *$ & 0.000 & 0.000 & -0.000 \\
\hline & $(0.001)$ & $(0.001)$ & $(0.001)$ & $(0.001)$ & $(0.001)$ & $(0.001)$ & $(0.001)$ & $(0.001)$ & $(0.001)$ \\
\hline Estimators & AHIV & GMM & SYSGMM & AHIV & GMM & SYSGMM & AHIV & GMM & SYSGMM \\
\hline Observations & 8,819 & 8,819 & 10,209 & 2,668 & 2,668 & 3,147 & 1,841 & 1,841 & 2,167 \\
\hline Number of firms & 1340 & 1340 & 1340 & 446 & 446 & 446 & 316 & 316 & 316 \\
\hline$A R 2$ test & -0.407 & -0.433 & -0.354 & 0.0672 & 0.0987 & 0.149 & 2.353 & 2.228 & 2.232 \\
\hline Sargan test & - & 246.1 & 292.5 & - & 152.4 & 191.7 & - & 156.0 & 169.4 \\
\hline$F$-test 1 & $38.56^{* * *}$ & $50.59 * * *$ & $46.17 * * *$ & $4.28 * *$ & $14.05 * * *$ & $22.91 * * *$ & $6.93 * * *$ & $17.19 * * *$ & $15.56^{* * *}$ \\
\hline$F$-test 2 & $1851.18^{* * *}$ & $1972.52 * * *$ & $3508.82 * * *$ & $441.25 * * *$ & $503.98^{* * *}$ & $679.19 * * *$ & $109.73 * * *$ & $113.35^{* * *}$ & $195.10 * * *$ \\
\hline
\end{tabular}

Notes: This table reports the estimation results for the augmented error correction model of leverage that nests the pecking order theory specified by Equation (11), as follows:

$$
\Delta D_{i t}=\alpha+\lambda T L C_{i t}+\gamma L E C M_{i t}+\beta D E F_{i t}+u_{i t}
$$

where $\Delta D_{i t}$ is book leverage change. $T L C_{i t}$ and $L E C M_{i t}$ denote target (book) leverage change and (lagged) deviation from target (book) leverage (i.e., lagged error correction term), respectively. See target (book) leverage estimations in Table 8. DEF is the cash flow deficit variable, defined by Equation (9). AHIV denotes the Anderson and Hsiao's (1982) instrumental variable estimator. GMM and SYSGMM denote Arellano and Bond's (1991) and Blundell and Bond's (1998) estimators, respectively. AR2 test is a test for second-order serial correlation, under the null of no serial correlation. Sargan test is a test for over-identifying restrictions under the null of valid instruments. $F$-test 1 is a test for the difference between the coefficients $T L C_{i t}$ and $L E C M_{i t}$, under the null of no difference, $T L C_{i t}=L E C M_{i t}$. F-test 2 is the test for the null hypothesis that $\beta=1$. Robust standard errors of coefficients are reported in parentheses. $* * *$ and $* * *$ indicate the coefficient significant at the $10 \%, 5 \%$ and $1 \%$ levels, respectively 